\title{
THE POSITION OF MAQASID AL-SHARI'A ON FIQH OF MINORITIES
}

\author{
Moh. Wahib ${ }^{1}$ \\ Sabri Samin ${ }^{2}$ \\ Barsihannoor $^{3}$ \\ Muhammad Shuhufi ${ }^{4}$ \\ Alauddin State Islamic University of Makassar ${ }^{1,2,3,4}$
}

\begin{abstract}
This paper elaborated in-depth on the position of maqasid alshari'a on fiqh of minorities. This study was descriptive library research. It used normative (shar'i) and sociological theological approaches. The primary data sources were data obtained through literature studies that were taken from the al-Qur'an, hadith, fiqh books, books that reviewed fiqh of minorities, or other sources that were related to this study. The results showed that the position of maqasid al-shari'a was a basis and foundation for the concept of fiqh of minorities. The format of the maqasid al-shari'a rules in fiqh of minorities included: First, al-taysir waraf 'al-haraj (easing and taking up difficulties). Second, tagayyur al-fatwa, that is changes in the fatwa. Third, tanzil al-hajah manzilah al-darurat (needs to occupy an emergency). Fourth, 'Urf or customs in society. Fifth, Annazru ila alMa'alat (seeing the legal consequences). Sixth, the jamaah as the judge.
\end{abstract}

Keywords: Maqasid al-Shari'a; Fiqh of Minorities

\section{INTRODUCTION}

The problems related to the early emergence of the concept of minorities are the problems of Muslim minorities in Europe and America. This is because their lives are more complex than anywhere else. Besides, non-Muslims in Europe and America live in developed countries with a complex atmosphere. Moreover, the number of the Muslim population in Europe is increasing, along with the migration to European countries from Muslims who are from Arab countries which are close to Europe.

There is also the possibility that minorities in other countries experience the same legal problems. For example, this happens in Hong Kong and Taiwan. Many TKW (Female Migrant Workers) in those countries work with their employers who ask them to cook pork. It is difficult for the worker to refuse. As a solution to this problem, they are permissible to work, as long as there is no other work, and they certainly do not consume the pork.

The association of Muslims and non-Muslims is problematic for Muslim minorities who live in Western countries. Muslim minorities need fiqh of minorities. Muslim minorities are awaiting studies and products of fiqh of minorities. The study of maqasid al-shari' $a$ has progressed in the midst of contemporary usul fiqh scholars to solve contemporary fiqh problems, for example by al-Syatibi and Wahbah al-Zuhaili, while scientific works reviewing the correlation between fiqh of minorities and maqasid al-shari'a are still limited. 
Islam brings mercy to the universe (rahmatan li-al-'alamin), not only to li-alaksariyyah (for the majority), but also to li-al-aqalliyyah (for the minority). International relations in the global era demand openness, cannot be exclusive. The association of Muslims and non-Muslims requires intensive interaction, such as friendship, neighborhood, and family relationships. Furthermore, in the global era today, it is impossible to isolate oneself from association with other religious adherents.

The characteristics of Islamic law is easy in its practice. Allah Almighty does not make Islam an issue that makes people have difficulties. Likewise, shari'a brings benefits to humans. Islamic scholars and legal experts in this case must be responsive by offering the concept of fiqh of minorities and maqasid al-shari'a. Scientific works that examine ijtihad of fiqh of minorities and its correlation with maqasid al-shari'a must be abundant because the problems of Islamic law are so dynamic.

The Muslim minority is spread all over the world following the spread of Islam which is spread by the scholars. This is part of the prophetic mission as rahmatan li-al'alamin. In general, the Muslim minority that has been the concern of the scholars is a Muslim minority who live and domicile in the West, including on the continents of Europe and America. The minority is a term for a group of people in a country that is different from most of the population of that country. These differences can be in the form of differences in religion, school of thought, heredity, language, and other basic aspects that differentiate a group of humans and other humans. Examples of minorities are Christian in Egypt, Syria, and Iraq, Jews in Morocco, Iran, Muslims in European and American countries. ${ }^{1}$

Regarding maqasid al-shari'a, the implementation of fiqh of Muslim minorities is closely related to maslahat hajjiyyah, which is maslahat that will cause difficulties for humans if ignored, ${ }^{2}$ in this case related to the difficulty of interacting between religious communities. On the other hand, if this maslahat is realized, it will manifest convenience, serenity, and peace. Human life will feel peaceful, harmonious, and respectful.

The application of fiqh of minorities in Muslim minority areas is rarely studied by fuqaha or in scientific studies. The literature on fiqh of minorities is still limited. Particularly, in the scope of Muslim scholars and intellectuals in Indonesia, it is still rarely found. Seminars and scientific forums that discuss and review fiqh of minorities themes are still few. Therefore, Muslim intellectuals, scholars, and academics in higher education are required to further elaborate on the concept of fiqh of minorities.

The study of maqasid al-shari'a is increasingly prevalent in contemporary Islamic legal studies. Maqasid al-shari'a has the relevance that the mujtahids really

\footnotetext{
${ }^{1}$ The Muslim minority in the West can be detailed as follows: Native Turks, Albanians, Kosovo, Croats, Serbs, Bulgarians, and so on, European who recently converts to Islam (muallaf), Moroccan immigrants in France, Turkish immigrants in Germany, Indian, Pakistan, and Bangladesh immigrants in England. There are also Muslims in the Netherlands, Belgium, Austria, Italy, Spain, Scandinavian countries, etc. The Muslim minority in the East can be detailed as follows: 150 million Muslims in India, the former Soviet Union, including Uzbekistan, Tajikistan, Kazakhstan, Azerbaijan, 20 million Muslims in Russia from Chechnya, 150 million Muslims in China, Ethiopian Muslims, Erytheriam Chad, the minority in Thailand (Patani), the Rohingya Tribe in Myanmar, Sri Lanka, Nigeria, Ghana, etc. See Yusuf Al-Qaradawi Fiqh al-Aqalliyyat, Maktabah Wahbah Qahirah, 2012 pp. 13.

${ }^{2}$ Wahbah al-Zuhaili, Usul al-Fiqh al Islamy(Edition I; Teheran: DarEhsan, 1997), pp. 156.
} 
pay attention to in solving many contemporary cases that have never emerged in the community. Likewise, it is also needed for cases that have occurred before, but require a legal conclusion. In this case, it relates to selecting opinions that are relevant and suitable to be applied among the people. Therefore, the study of maqasid is an interesting study discussed by scholars and practitioners of Islamic law. This paper elaborates in-depth on the position of maqasid al-shari'a on fiqh of minorities.

\section{RESEARCH METHODOLOGY}

This study was descriptive library research. It used normative (shar'i) and sociological theological approaches. The primary data sources were data obtained through literature studies that were taken from the al-Qur'an, hadith, fiqh books, books that reviewed fiqh of minorities, or other sources that were related to this study. The data collection was carried out by searching through literature, classical, and contemporary holy books to obtain relevant data, then sorting and compiling. The primary data were collected first as the main variable and followed by classification and categorization. Techniques used for processing and analyzing data were by searching and arranging systematically by organizing data into categories, describing them into units, synthesizing, arranging them into patterns, choosing which ones are important and which will be studied, and drawing conclusions so that they are easily understood by ourselves and others.

\section{RESULTS AND DISCUSSION}

1. The Book on the Theme of Maqasid Al-Shari'a was Written Before Fiqh of Minorities

Of the many scholars who wrote the theme of fiqh of minorities concepts, they preceded it with an in-depth study of maqasid al-shari'a. This is proof that the concept of fiqh aqalliyat (fiqh of minorities) is based on the big concept of maqasid al-shari'a. The group of scholars and their thoughts on maqasid al-shari'a include Yusuf Qaradawi who wrote a book entitled Dirasah Fi Fiqh Maqasid Al-Shari'ah. This book was written by Qaradawi before formulating the concept of fiqh of minorities. According to him, his books discussing the law for minorities are all based on maqasid al-shari'a, which is the benefit of mankind. ${ }^{3}$ According to Qaradawi's statement, who is the main originator of the concept of fiqh of minorities, it is clear that maqasid alshari'a is an important stepping stone for the emergence of his thoughts on fiqh of minorities.

In his book titled Dirasah Fi fiqh Maqasid al-Syariah, Qaradawi stated that he has long believed in the existence of maqasid al-shari' $a$ and the importance of maqasid al-shari'a for furaqa in understanding the matters of al-shari'a and doing ijtihad to

${ }^{3}$ Yusuf Qaradawi, Dirasah fi Fiqh Maqasid al-Syari'ah; baina al-Maqasid al-Kulliyah wa alNusus al-Juziyyah, pp. 76. 
establish new laws. Qaradawi ${ }^{4}$ honestly admits that the books he wrote about fiqh of minorities arose from his awareness of maqasid al-shari' $a{ }^{5}$

Meanwhile, Taha Jabir al-Alwani, another initiator of fiqh of minorities linked the theory of fiqh of minorities to maqasid in his book titled Maqasid al-Shari'a. He wrote this maqasid book before writing a book on fiqh of minorities. In this book, alAlwani combines the discussion between maqasid al-shari' $a$ with fiqh of minorities. ${ }^{6}$

It can be understood that al-Alwani, the initiator of this fiqh of minorities, had a deep knowledge of maqasid al-shari'a, before proposing and supporting the idea of fiqh of minorities. With his deep understanding of maqasid al-shari'a, he could develop it into the theory and concept of fiqh of minorities that he initiated in the North American continent. The institution he pioneered was an international Islamic thought organization, followed by establishing a fatwa assembly in North America called the FCNA (Fiqh Council of North America) in 1994 ${ }^{7}$. He then recruited his daughter, Zainab al-Alwani to continue his trail of service in the Fiqh Council of North America. Muslims living in North America greatly benefit from the existence of the FCNA (Fiqh Council of North America). This institution accommodates many muftis who are Muslim scholars and academics who teach at various universities in North America.

Meanwhile, Abdullah Bin Biyyah, who is one of the supporters of the fiqh of minorities theory, wrote scientific papers discussing fiqh of minorities. As the former Mufti of Mauritania, he is a member of the editorial board of the European Council of Fatwa magazine. His book, sina'at fatawa wa fiqh al-aqalliyyat also contains an attachment to the fatwa of the European council for fatwa and research which he elaborated with very detailed comments. ${ }^{8}$ Before writing this book, he wrote the book 'Alaqat maqasid al-syari'ah bi usul al-fiqh. He provides six basic rules in fiqh aqalliyyat which are closely related to the theory of maqasid al-shari'a. ${ }^{9}$ This is evidence that before he wrote the concept of fiqh of minorities, he has written many books on maqasid al-shari'a. Abdullah Bin Biyyah is a Muslim intellectual who has actively participated in establishing fatwas for European Muslim minorities. It can be seen from many fatwas issued by the European Council of Fatwa which he commented on and responded to in his book. His broad understanding of maqasid al-shari'a led him to support the concept of fiqh of minorities.

Meanwhile Jaser Audah, one of the supporters of the theory of fiqh of minorities wrote a very comprehensive book on maqasid al-shari'a, titled Fiqh alMaqasid. When discussing maqasid, he wrote a theme titled tatbiqat Ala Fiqh AlAqalliyyat as an application. ${ }^{10}$ Jaser Audah tried to describe the practice of fiqh of minorities based on maqasid al-shari'a. He is a Muslim intellectual who has great

${ }^{4}$ Yusuf Qaradawi, Dirasah fi Fiqh Maqasid al-Syari'ah; baina al-Maqasid al-Kulliyah wa alNusus al-Juziyyah, pp. 11.

${ }^{5}$ Yusuf Qaradawi, Dirasah fi Fiqh Maqasid al-Syari'ah; baina al-Maqasid al-Kulliyah wa alNusus al-Juziyyah, pp. 14.

${ }^{6}$ Taha Jabir, al-Alwani, Maqasid al-syariah, (Edition I.; Washington: IIIT, 1996), pp. 23

${ }^{7}$ Imam Mawardi, Fikih minoritas, fiqh al-aqalliyyat dan evolusi maqashid al-syariah dari konsep ke pendekatan, pp.11.

${ }^{8}$ Abdullah bin Biyyah, Sinaat al-Fatwa Wa fiqh al-Aqalliyyat, pp. 12.

${ }^{9}$ Abdullah bin Biyyah, Sinaat al-Fatwa Wa fiqh al-Aqalliyyat, pp. 13.

${ }^{10}$ Jaser Audah, Fiqh Maqashid(Edition I; al-Qahirah: Dar al-Syuruq,2007), pp. 54. 
concern for fiqh of minorities. Thus, based on this explanation, it is clearly understood that fiqh of minorities is based and rests on maqasid al-shari'a.

Of the many scholars who wrote about fiqh of minorities, it is clear that they preceded it with a deep study of maqasid al-shari' $a$. This is evidence that the concept of fiqh aqalliyat (minority) is based on maqasid al-shari'a. Based on the literature research conducted by the researchers, it is evident that the concept of maqasid alshari'a developed by contemporary Muslim figures led to the concept of fiqh of minorities theory.

2. The Concept of Maqasid Al-Shari'ah Appeared Before the Concept of Fiqh of Minorities.

The concept of maqasid al-shari'a has emerged since the time of Imam alHaramain. The most popular one is since the time of Imam al-Syatibi, but have been started at an earlier time. ${ }^{11}$ According to al-Raisuni, maqasid al-shari'a has been discussed for a long time by usul fiqh scholars in various books, but it is still unorganized and not systematic. Of the four school scholars who first discussed maqasid is Imam Juwaini, a scholar who follows the Syafii school of thought. He is considered as an imam and a pioneer in maqasid in the initial phase. ${ }^{12}$ The next is AlGazali, who also follows the Syafii school of thought. Then, the second pioneer is Izz al-Din bin Abd al-Salam, who is also a scholar of followers of the Shafi school of thought, followed by his student al-Qarafi, an ulama who follows the Malik school of thought. The third pioneer is al-Syatibi who follows the Malik school of thought. It is followed by Ibn Taimiyyah and Ibn al-Qayyim. Lastly, the fourth imam or pioneer is Tahir Bin 'Asyur, followed by Allal al-Fasi. While the contemporary scholars of maqasid al-shari'a are Abdullah bin Biyyah and Jamal al-Din Atiyyah. ${ }^{13}$

The concept of fiqh of minorities has only been raised and popularized by two contemporary Muslim intellectuals or scholars, Yusuf Qaradawi and Taha Jabir alAlwani. The term fiqh al-aqalliyyat did not appear until the early 1990s. It was precisely when Taha Jabir used this term for the first time in 1994 when the FCNA (Fiqh Council of North America) he led issued a fatwa that it is "permissible" for American Muslims to give their voting rights in the American presidential election, which incidentally the candidate is non-Muslim. Then, Taha Jabir wrote several writings related to fiqh al-Aqalliyyat, such as nazrat ta'sisiyyah fi fiqh al-Aqalliyyat and Towards a Fiqh for Minorities: Some Basic Reflection. Meanwhile, Yusuf Qaradawi founded ECFR (European Council for Fatwa and Research) in London in 1997 with the main objective of providing Islamic legal services to the European Muslim minority community. ${ }^{14}$

Therefore, it can be concluded that the concept of maqasid al-shari'a became the inspiration for the emergence of the concept of the fiqh of minorities. From the time span and the very long difference in years between the emergence of maqasid alshari'a and fiqh of minorities, it is clear that the theory of maqasid al-shari'a took longer to emerge and develop. Once the theory of maqasid al-shari'a was known and

\footnotetext{
${ }^{11}$ Ahmad al-Raisuni, Muhadarat fi maqasid al-syariah, pp. 43.

${ }^{12}$ Ahmad al-Raisuni, Muhadarat fi maqasid al-syariah, pp. 153.

${ }^{13}$ Ahmad al-Raisuni, Muhadarat fi maqasid al-syariah, pp. 153.

${ }^{14}$ Imam Mawardi, Fikih minoritas, fiqh al-aqalliyyat dan evolusi maqasid al-syariah dari konsep ke pendekatan, pp.11.
} 
published by scholars, the fiqh of minorities theory emerged, starting in America and Europe.

3. Maqasid Principles Become the Foundation and Basis of Fiqh of Minorities

Yusri Ibrahim stated that there are five contents of maqasid al-shari'a which are the starting points for the concept of fiqh of minorities, including:

First: Iqamat al-din baina al-aqalliyyat al-muslimah, which means upholding religion among the Muslim minority. Hifz al-din, which is part of maqasid al-shari'a, is the most important stepping point for the concept of fiqh of minorities. It means maintaining religion, both religion at the individual and congregational level (Muslims). ${ }^{15}$ Hifz al-din or upholding the religion of Islam is the most important maqasid (goal of Islamic law). In this case, maintaining religion is maintaining the existence of the Muslim religion, both individually and in the community by following the word of Allah Almighty in QS al-Rum/30:43
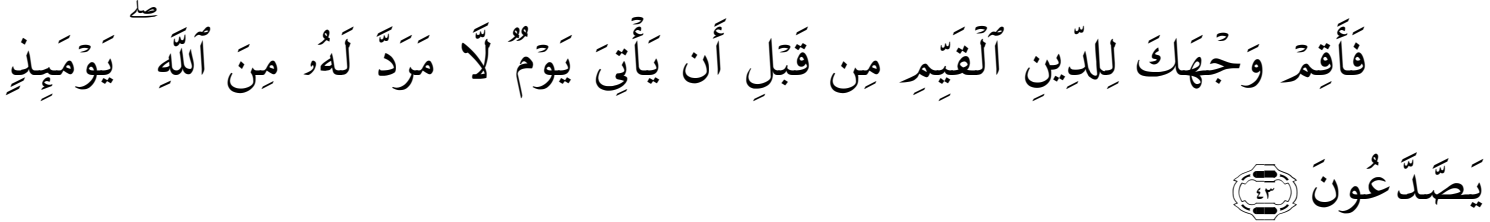

Translation:

"So direct your face toward the correct religion before a Day comes from Allah of which there is no repelling. That Day, they will be divided." 6

Allah says in QS al-Syura/42:13

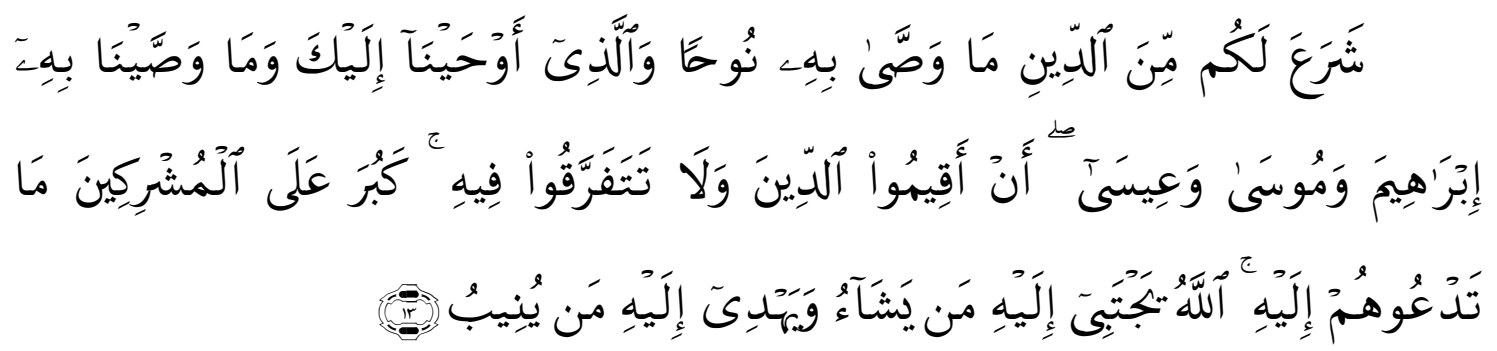

Translation:

"He has ordained for you of religion what He enjoined upon Noah and that which We have revealed to you, [O Muhammad], and what We enjoined upon Abraham and Moses and Jesus - to establish the religion and not be divided therein. Difficult for those who associate others with Allah is that to which you invite them. Allah chooses for Himself whom He wills and guides to Himself whoever turns back [to Him]. ${ }^{, 17}$

\footnotetext{
${ }^{15}$ Muhammad Yusri Ibrahim, Fiqh al-Nawazil li al-Aqalliyyat al-Muslimah, ta'shilan wa tatbiiqan pp. 269.

${ }^{16}$ Ministry of Religion of the Republic of Indonesia, Al-Qur'an dan Terjemahnya, pp. 178.

${ }^{17}$ Ministry of Religion of the Republic of Indonesia, Al-Qur'an dan Terjemahnya, pp. 230.
} 
Yusri added that the concept of fiqh of minorities is an effort to safeguard the religion of Islam, both its syiar, its principles of faith, and its morals, individually and in the congregation, for male or female. ${ }^{18}$

Second: Maintain Islamic preaching. This is part of maintaining religion which is the first order in al-kulliyyat al-khamsah. In this case, the concept of fiqh of minorities seeks to preach Islamic law to non-Muslims. ${ }^{19}$ The point of Yusri's statement is that the concept of fiqh of minorities aims to preach Islam to nonMuslims. The concept of fiqh of minorities is to be open and socialize inclusively, and commit to living together with non-Muslims in one country. Muslims do not isolate themselves and should interact openly with non-Muslims. For example, it can be seen by saying merry Christmas to others who celebrate Christmas. Such an attitude will lead to a polite da'wah model that will soften the hearts of non-Muslims. They will be touched by their hearts and willing to be invited to convert to Islam without violence. By looking at friendly Muslim morals, this is a bi-al-hal da'wah (with an attitude of action) that is included in the effort to protect religion, which is by applying amar ma'ruf and nahi munkar.

Third: Taysir and raf'a al-haraj which are the objectives of al-shari'a, because Islamic law eliminates difficulties for humans based on the explanation of QS: alHajj/22:78.

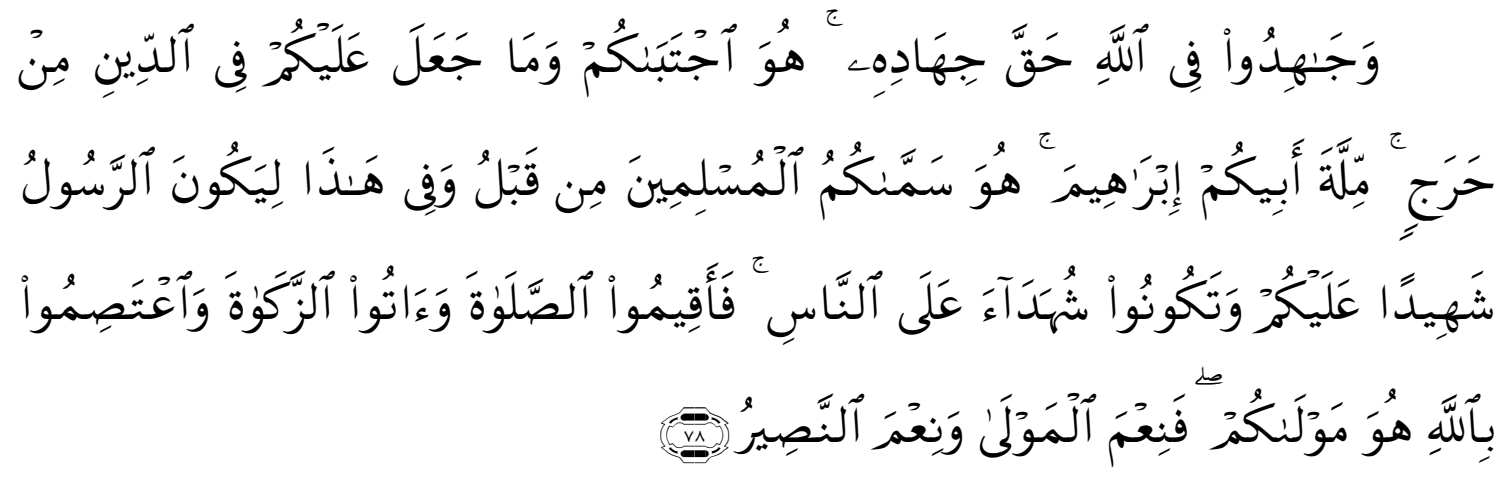

Translation:

"And strive for Allah with the striving due to Him. He has chosen you and has not placed upon you in the religion any difficulty. [It is] the religion of your father, Abraham. Allah named you "Muslims" before [in former scriptures] and in this [revelation] that the Messenger may be a witness over you and you may be witnesses over the people. So establish prayer and give zakah and hold fast to Allah. He is your protector; and excellent is the protector, and excellent is the helper. ${ }^{20}$

And the explanation of QS al-Baqarah/2:185.

\footnotetext{
${ }^{18}$ Muhammad Yusri Ibrahim, Fiqh al-Nawazil li-al-Aqalliyyat al-Muslimah, ta'shilan wa tatbiqan pp. 269.

${ }^{19}$ Muhammad Yusri Ibrahim, Fiqh al-Nawazil li-al-Aqalliyyat al-Muslimah, ta'shilan wa tatbiqan pp. 269.

${ }^{20}$ Ministry of Religion of the Republic of Indonesia, al-Qur'an dan terjemahnya, pp.163
} 


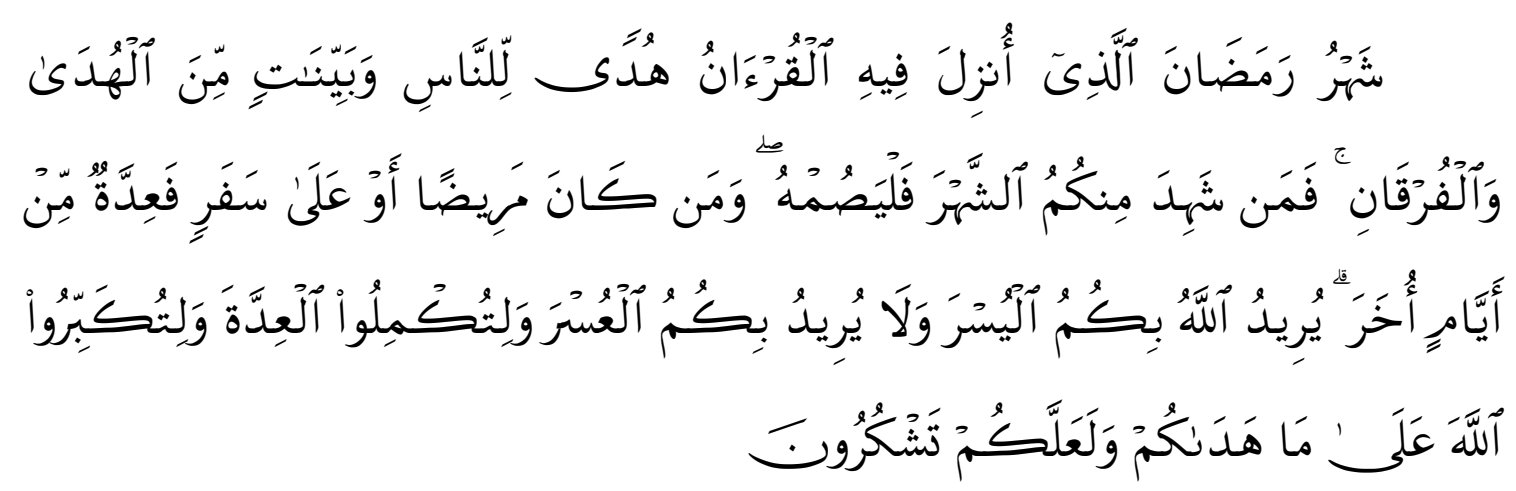

Translation:

"The month of Ramadhan [is that] in which was revealed the Qur'an, a guidance for the people and clear proofs of guidance and criterion. So whoever sights [the new moon of] the month, let him fast it; and whoever is ill or on a journey - then an equal number of other days. Allah intends for you ease and does not intend for you hardship and [wants] for you to complete the period and to glorify Allah for that [to] which He has guided you; and perhaps you will be grateful. ${ }^{, 21}$

In this case, it is in line with the principle of maqasid, which is hifz hajjiyyat. The concept of hajiyyat is to eliminate difficulties. Muslims in the West feel that their lives are difficult when fiqh of minorities is not applied. Wahbah al-Zuhaili, an expert on the usul fiqh and contemporary fiqh, wrote that the concept of hajiyyat in maqasid is to eliminate difficulties. ${ }^{22}$

Fourth: Hifz jama'ah, in this case is to maintain togetherness. ${ }^{23}$ It means togetherness among the Muslim minority community, and not only their personal existence. With the concept of fiqh of minorities that provides solutions to their problems, this is a form of respect for their dignity and self-respect as congregations or Muslim minority communities. This is because they are far from their families because they have migrated, and are alienated from the majority group. With the concept of fiqh of minorities, they feel that their existence and social needs are concerned.

Yusri Ibrahim's statement about protecting the congregation (togetherness) is part of hajjiyyat, which is a group or social needs. This is because the group is an effort to simplify the affairs of life. Humans are social creatures who need help from others. If each of them lives alone in isolation, it will result in difficulties and burdens of life. In this modern era with sophisticated communication tools, Muslims feel as a congregation in the community or state. The world has become globalized, so there is a need for more intensive interactions between Muslims and non-Muslims. When Muslims isolate themselves, it will result in many misunderstandings and disputes with fellow citizens living in the West.

\footnotetext{
${ }^{21}$ Ministry of Religion of the Republic of Indonesia, al-Qur'an dan terjemahnya, pp. 200.

${ }^{22}$ Wahbah al-Zuhaili, Usul al-fiqh al-Islami, juz 2 pp. 23.

${ }^{23}$ Muhammad Yusri Ibrahim, Fiqh al-Nawazil Li al-Aqalliyyat al-Muslimah, Ta'shilan Wa Tatbiiqan, pp. 211.
} 
Fifth: Rukhshah or ease. ${ }^{24}$ What Yusri stated is also part of maintaining hajjiyyat. In the concept of hajjiyyat, difficulties and burdens must be removed. At this point, the concept of fiqh of minorities is based on maslahat of hajjiyyat which is part of maqasid al-shari'a. Yusri Ibrahim's statement further strengthens the conclusion that the concept of fiqh of minorities is based on maqasid al-shari'a.

According to Yusri, this fiqh of minorities is based on maqasid which can be traced in the historical practice of the Prophet. That is when the Muslims were recently growing and developing in Mecca with a small number. This is in line with the explanation in QS al-Anfal/8:26.

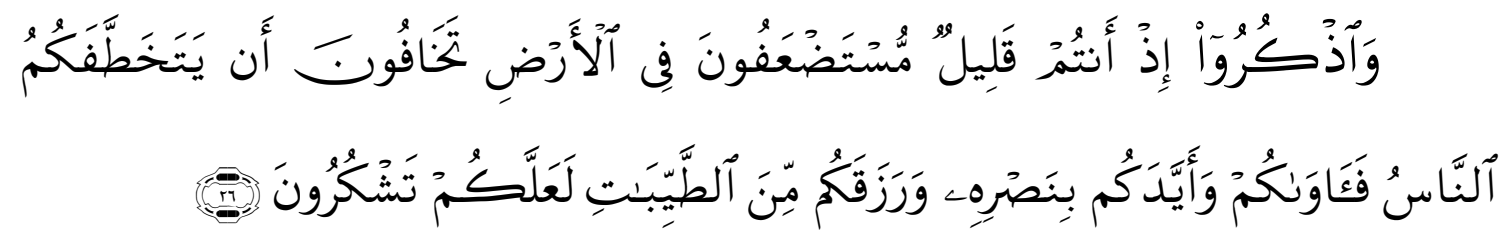

Translation:

"And remember when you were few and oppressed in the land, fearing that people might abduct you, but He sheltered you, supported you with His victory, and provided you with good things - that you might be grateful. ${ }^{95}$

In this case, the Prophet Muhammad carried out a strategy of restraint and did not take resistance because the number of Muslims was still small. Even the Prophet maintained a patient and restrained attitude until Sumayyah and Yasir were killed in Mecca. Sumayyah was thrown with a spear by Abu Jahl at close range while pregnant. While her husband, Yasir, was brutally murdered in front of their son, Ammar. With the strategy of restraining oneself and not revenge on the crimes of the polytheists of Mecca, this all shows the maintenance of maqasid al-shari'a and its benefit. If the Muslims under the leadership of the Prophet were frontal and blindly at that time, it would result in greater damage. ${ }^{26}$

Meanwhile, Abdullah bin Bayyah also strengthened the message that the concept of fiqh of minorities is based on the maqasid al-sharia. He concluded this by explaining the four aims of fiqh of minorities. First: Maintaining the existence of Muslim minorities, both individuals and congregations. ${ }^{27}$ Based on the explanation of bin Biyyah, it can be concluded that the concept of fiqh of minorities is appropriate and relevant by relying on one of the al-daruriyyat al-khamsah, which is hifz al-din (maintaining religion). Every Muslim, wherever he or she is, is always bound by the obligation to carry out Islamic law, whether he or she is in the majority or minority group. It is included Muslim minorities in the world, either in Europe, America, or in Indonesia, which are in areas with a minority group, for example Papua, North Sulawesi, Bali, NTT, and in several places in North Sumatera. The explanation of bin Bayyah strengthens the conclusion that the concept of fiqh of minorities is based on the major concept of maqasid al-sharia. The existence of the concept of fiqh of

\footnotetext{
${ }^{24}$ Muhammad Yusri Ibrahim, Fiqh al-Nawazil Li al-Aqalliyyat al-Muslimah, Ta'shilan Wa Tatbiqan, pp. 211.

${ }^{25}$ Ministry of Religion of the Republic of Indonesia, al-Qur'an dan terjemahnya, pp.189.

${ }^{26}$ Muhammad Yusri, Fiqh al-Nawazil Li al-Aqalliyyat Almuslimah, Ta'shilan Wa Tatbiqan, pp. 514.

${ }^{27}$ Abdullah bin Syaikh Bin Biyyah, Sinaat al-Fatwa Wa fiqh al-Aqalliyyat, pp. 229.
} 
minorities is not merely a new idea, but is really very urgent to maintain the diversity of Muslims, especially in countries and regions with minority groups.

Second: The second objective of fiqh of minorities is to spread Islamic preaching. This da'wah is closely related to al-daruriyyat al-khamsah, which is hifz aldin, with the provision of amar makruf nahi munkar to protect Islam. ${ }^{28}$ Islamic da'wah is spread throughout the world and carries the mission of amar makruf nahi munkar. Maintaining religion with amar makruf nahi munkar means that the teachings of Islam can exist whenever there is practice of amar makruf nahi munkar. Thereby, this fiqh of minorities encourages efforts to protect religion, which includes amar makruf nahi munkar. Wahbah al-Zuhaili, an expert on usul fiqh, stated that one of the efforts to protect religion is jihad to defend the religion of Allah. ${ }^{29}$ In this context, da'wah is one part of jihad to protect the religion of Allah Almighty.

Third: The third objective of fiqh of minorities is to maintain good relations with non-Muslims in this increasingly global reality. ${ }^{30}$ Thus, this is in line with hajjiyyah which can cause difficulties if an individual isolate from associating with non-Muslims. Moreover, Muslims and world citizens now are connected with very easy communication and interaction.

Association between religions is very necessary to maintain good relations among humans that are tied to equality of citizenship, equality of nation, and homeland. Thus, it is very necessary to have intensive interaction between religious adherents to maintain harmony in life. It can be seen that the concept of fiqh of minorities is very urgent to build a harmonious interaction between religions. This includes the benefits of hajjiyyah which is an indispensable need, especially in the global era.

Fourth: The fourth objective of the concept of fiqh of minorities is to maintain congregational fiqh, from which individual and group orientations become global orientations in associating with non-Muslims. ${ }^{31}$ As it is analyzed, this is included as the realm of mukammil al-daruri, for example the congregational prayer mentioned by al-Zuhaili as mukammil al-daruri. ${ }^{32}$

Fiqh of minorities, which follows the dynamics of changing times, is greatly influenced by the concepts and theories of ijtihad based on maqasid al-sharia. For this reason, many experts currently use maqasid as a means of ijtihad which is widely used in answering the very dynamic problems of contemporary fiqh. For example, it can be seen in the prohibition of traveling for women unless accompanied by a mahram. So, the fuqaha of maqasid see the purpose of the Prophet in prohibiting the woman's safar, which is the fear of robbery on the road. This is different from means of transportation today, for example public transportation, trains, and planes. Nowadays, they are assured of their safety from harassment by irresponsible men. Therefore, this prohibition has turned into the permissibility for a woman to travel without a mahram. Today, a woman can travel without a mahram as long as safety is guaranteed.

Likewise, there is an issue regarding the use of toothpaste. It is equated with the miswak mentioned in the Prophet's hadith. Contemporary fuqaha, for example Al-

\footnotetext{
${ }^{28}$ Bin Biyyah, Sinaat al-Fatwa Wa fiqh al-Aqalliyyat, pp. 229.

${ }^{29}$ Wahbah al-Zuhaili, Usul al-fiqh al-Islami, juz 2 pp.1024.

${ }^{30}$ Bin Biyyah, Sinaat al-Fatwa Wa fiqh Al-Aqalliyyat, pp. 229.

${ }^{31}$ Bin Biyyah, Sinaat al-Fatwa Wa fiqh Al-Aqalliyyat, pp. 229.

${ }^{32}$ Wahbah al-Zuhaili, Usul al-fiqh Al-Islami, juz 2 pp. 1024.
} 
Malibari in his book Fath Al-Muin, equates toothpaste or fursyah with miswak. ${ }^{33}$ Likewise, Al-Zuhaili stated that istinja using stones could be replaced with tissue, as long as the uncleanness is not spread over the feet. ${ }^{34}$ This can also be seen in the war equipment, which previously mentioned as quwwah and ribat al-khail. They are now have changed into bombs, cannons, missiles, barracuda, and tanks. ${ }^{35}$

The concept of fiqh of minorities is a special legal rule because it is in a state of emergency and necessity. ${ }^{36}$ Thus, the concept of maqasid al-sharia meets the concept of hajjiiyyat. The concept of fiqh of minorities is a form of moderate attitude because it is in line with reality or waqi but does not exaggerate or transcend boundaries. ${ }^{37}$ Qaradawi mentions in fiqh of maqasid about the ideal moderation in maqasid. ${ }^{38}$ This is also stated by Musfir Qahtani who considered that concern to maqasid al-sharia is an effort to implement a moderate attitude in Islam. Not only dwelling on the text, but also on the spirit and objectives of the shari'a. ${ }^{39}$

Therefore, the practice and concept of fiqh of minorities are in line with the concept of maqasid al-sharia which is rooted in the mission of rahmatan li al-Alamin of Rasulullah by providing convenience. This fiqh of minorities is also related to hifz alnafs (guarding the soul) which is in the second order in al-kulliyyat alkhamsah. ${ }^{40}$ This is related to the guarding of souls related to the friction of the relationship between Muslim minorities and non-Muslim majorities. As observed, this struggle between majority and minority groups is very vulnerable to strife and conflict. For example, it can be seen in Rohingya Muslims in Myanmar. For a long time, the Muslims were oppressed by the ruling majority in Myanmar. One of the solutions that have been offered by Indonesia is maintaining good relations with the majority. This is shown, for example, by the Indonesian government which maintains relations with various religious adherents.

Qaradawi further explained the existence of maqasid al-sharia as a basis for fiqh of minorities. He stated that the attitude of minorities, for example those in Europe, must be accommodative and integrative with non-Muslims, not carrying out 'uzlah or staying away from social interactions. He stated that the appearance of the Muslims should not be an issue compared to the appearance of non-Muslims. It is because the hadith that is related to differences in appearance shows that it was at the time of the Prophet and is not in accordance with its application today. Thus, it is better if Muslim minorities in Europe should maintain their appearance as they are by adjusting to the appearance of non-Muslims, which is wearing pants, without having to make a new look. This is because indeed the ideal is to show the point of unity and not to exaggerate the differences with non-Muslims. The appearance of a woman wearing a

\footnotetext{
${ }^{33}$ Zain al-Din al-Malibari, Fath al-Mu'in, pp. 23.

${ }^{34}$ Wahbah al-Zuhaili, Usul al-Fiqh al-Islami pp. 69.

${ }^{35}$ Yusuf Qaradawi, Kaifa Nata'amalu Ma'a al-Qur'an, (Edition I; Al-Qahirah, Maktabah Wahbah, 1999), pp. 14

${ }^{36}$ Abdullah bin Syaikh Bin Biyyah, Sinaat al-Fatwa Wa fiqh al-Aqalliyyat, pp. 226.

${ }^{37}$ Imam Mawardi, Fikih minoritas, fiqh al-aqalliyyat dan evolusi maqashid al-syariah dari konsep ke pendekatan, pp. 245

${ }^{38}$ Yusuf Qaradawi, Dirasah fi Fiqh Maqasid al-Syari'ah; baina al-Maqasid al-Kulliyah wa alNusus al-Juziyyah, pp. 112

${ }^{39}$ Musfir Qahtani, al-Wa'yu al-Maqashidi, (Edition I; Beirut: Al-Syabakah Al-Arabiyyah, 2008), pp. 126

${ }^{40}$ Ahmad Raisuni, Muhadarat Fi al-Maqasid al-syariah, pp. 145
} 
hijab by covering her intimate parts is indeed an obligation thet must be implemented and there is no compromise. What should be a consideration is not to over-wear the niqab. $^{41}$

The accommodative attitude in dressing that does not violate the shari'a is the concept of maqasid al-sharia. In this case, Qaradawi explained it and included it in the discussion of al-bahsu 'an maqsad al-nas qabla isdar al-hukmi (looking for the meaning of the text before establishing the law). ${ }^{42}$ It can be clearly seen that Qaradawi rests on the concept of maqasid al-sharia when discussing the problems of the Islamic law of Muslim minorities in the West. Thus, this emphasizes the conclusion that the concept of fiqh of minorities is based on and rests on maqasid al-sharia.

Qaradawi explained the verse that a believer who claims to believe in Allah and His Apostles is demanded to be obedient and comply and there is no option to deny the obligation to carry out the shari'a that has been outlined by Allah and His Apostles. ${ }^{43}$ The meaning Qaradawi's is that wherever Muslims stand, they must practice their religious teachings, even when they leave their country to Muslim minority areas, for example in Europe or America. This is relevant to the character of Islam as rahmatan li al-alamin because the Prophet was indeed not sent only to the Arabs, but also to various nations in the world.

In the explanation of Surah Al-Hujurat, Allah Almighty creates human nations and tribes. Allah Almighty said the following in QS Al-Hujurat/49:13:

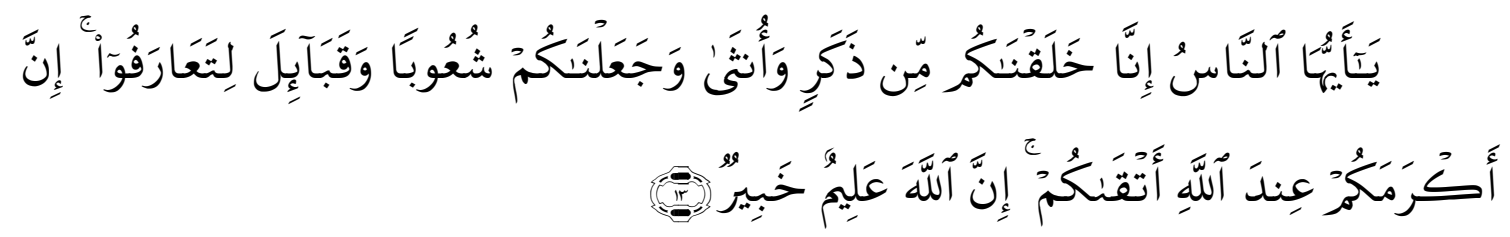

Translation:

"O mankind, indeed We have created you from male and female and made you peoples and tribes that you may know one another. Indeed, the most noble of you in the sight of Allah is the most righteous of you. Indeed, Allah is Knowing and Acquainted."

And, as it is examined in-depth, during the prophetic era of the Prophet Muhammad, nations and tribes became increasingly diverse. This is different from the prophetic function of the previous Apostles. For example, the Prophets Moses and Isa were only sent to the children of Israel, their own people. At the time of the Prophet, Islam had spread to various places. He also sent letters to various countries, such as Egypt, Rome, and Persia. He even sent companions to migrate to Habasyi or Ethiopia, a country that is different from Arab countries.

In the Medina market, many Muslims came into contact with various nations carrying merchandise and carrying out transactions, for example the Jews and the

\footnotetext{
${ }^{41}$ Yusuf Qaradawi, Dirasah fi Fiqh Maqasid al-Syari'ah; baina al-Maqasid al-Kulliyah wa alNusus al-Juziyyah, pp. 160.

${ }^{42}$ Y usuf Qaradawi, Dirasah fi Fiqh Maqasid al-Syari'ah; baina al-Maqasid al-Kulliyah wa alNusus al-Juziyyah, pp. 155.

${ }^{43}$ Y usuf Qaradawi, al-Islam Salihun Li al-tatbiq Fi kulli zaman wa makan, pp. 76.

${ }^{44}$ Ministry of Religion of the Republic of Indonesia, al-Quran dan Terjemahnya, pp. 165.
} 
Romans. Thus, Islam at the time of the Prophet had intersected with many nations. After the Prophet's death, Islam was spread by the companions and entered various countries with different conditions and places. This is what makes Islam rahmatan lial-alamin. While there were no other prophets after the Prophet Muhammad's death, the condition of Muslims in various areas experienced different conditions, both in terms of customs and geographical conditions and the diversity of their populations.

Islam had previously triumphed and controlled mainland Europe during the time of the Umayyad Caliphs in Spain. However, Islam in Europe became a minority over time. This is what encourages the concept of fiqh of minorities which is based on and relies on maqasid al-sharia, which is protecting the welfare of Muslims. The existence of Islam in Europe, America, and various places of minorities is related to the realm of hifz al-Din or protecting religion.

Imam Mawardi stated that fiqh of minorities as part of fiqh of maqasid alsharia bases istinbat of its law on general principles of maqasid al-sharia which emphasizes the urgency of universal values of Islam, objective, goal, wisdom, and illat. Benefit in all its aspects, and convenience of life are ideal conditions that must be established. This is a reflection that Islam is relevant and brings grace in all places and times. $^{45}$

As closely analyzed, Imam Mawardi's opinion is rooted in his understanding of the Prophet's mission as a bearer of mercy for the universe. Islam is not only spread in one point, such as in the Arab, but also in parts of European countries where the concept of fiqh of minorities has been emerging. Rahmatan lil al-Alamin means to bring goodness to mankind, by providing convenience, not difficulties. This is emphasized by the Prophet's words: "I was sent with a tolerant, easy religion". In other words of the Prophet: "You have been sent to make things easy (for the people) and you have not been sent to make things." In other words of the Prophet: "Tell the good news, and don't scare others. Make things easy for the people and do not make things difficult for them". Thus, the practice and concept of fiqh of minorities are in line with the concept of maqasid al-sharia which is rooted in the mission of maqasid al-sharia carried out by the Prophet Muhammad by applying the principle of convenience for humans.

This fiqh of minorities is also closely related to hifz al-nafs (guarding the soul) which is second in al-kulliyyat alkhamsah ${ }^{46}$. The meaning of this is that figh of minorities is closely related to protecting human souls or lives. This is carried out by avoiding conflicts between Muslim minorities and non-Muslim majorities. In the concept of fiqh of minorities, there is the principle of saving lives and avoiding an individual from horizontal conflicts that will cause human bloodshed.

As analyzed deeply, the association between the majority and the minority is very prone to create disputes and conflicts due to differences in religions and the number of adherents of each religion. For example, it can be seen in Myanmar which is related to Rohingya Muslims. For a long time, the Muslims were oppressed by the majority of non-Muslims who ruled in Myanmar. One solution that has been offered by Indonesia is that non-Muslim minorities need to maintain good relations with the

\footnotetext{
${ }^{45}$ Imam Mawardi, Fikih minoritas, Fiqh al-aqalliyyat dan evolusi maqashid al-syariah dari konsep ke pendekatan, pp. 256.

${ }^{46}$ Ahmad al-Raisuni, Muhadarat Fi al-Maqasid al-syariah, pp.145
} 
majority. Indonesia gave an example to Myanmar with its success in managing harmony and peace relations amidst religious diversity.

With the concept of Bhinneka Tunggal Ika on the basis of the Pancasila State, Indonesia has succeeded in realizing very harmonious relations between religious adherents until now. Although sometimes there are misunderstandings between religious adherents, there have never been prolonged horizontal conflicts. Incidents of inter-religious conflict in Indonesia can be resolved immediately by leaders, religious leaders, and local customary leaders.

One of the keys to maintaining harmony between religions is a flexible and adjustable attitude in saying Merry Christmas. The scholars said that the law of Christmas greetings is not only concerned with one opinion, which prohibits saying merry Christmas. However, there is still a second opinion that allows Christmas greetings, in which the congratulations are only in the form of an ordinary greeting, not believing in the heart. Until now, the MUI (Indonesian Ulama Council) has not declared Christmas greetings as haram, but has given the freedom for Muslims in Indonesia to choose between the two opinions that allow and prohibit Christmas greetings. With such legal status, it will be able to guarantee tolerance between religious communities, without sacrificing faith.

In the history of upheaval or conflict in a country, incidents of conflict between religions often occur, for example, the Uyghur Muslims in China and the Pattani in Thailand. Also, in Indonesia, there are religious conflicts in Ambon, Tolikara Papua, and the mosque minarets in Sentani, Papua. Such events will lead to conflict if not thoroughly solved, and even lead to bloodshed. Moreover, this definitely contradicts the concept of maqasid al-sharia which guards the blood or the soul. Thus, the concept of maqasid al-sharia needs to be applied to protect the soul or human life. The concept of fiqh of minorities is very suitable to apply because it contains an element of the maqasid al-sharia, which is hifz al-nafs (guarding the soul).

In relation to electing non-Muslim leaders, this is also to protect human souls. This is due to the fear of prolonged friction when Muslims do not participate in voting because the candidates for the election are non-Muslims. This happened in Papua Province. Because the majority of the population is Protestant, the candidates for governor and deputy governor are non-Muslims. Reluctance to elect the leaders will create suspicion and will raise a grudge between religious communities. Prospective leaders who are non-Muslim will assume that Muslims are abstaining and this will certainly damage good relations between religious communities. Even when a slight conflict occurs, it can result in casualties. ${ }^{47}$

Fiqh of minorities is also based on the principle of maqasid al-sharia, which is hifz mal, for example in relation to certain regional budgeting which includes Muslim minorities. The budget allocation is not in favor of Muslims if the concept of fiqh of minorities is not applied. In this case, the opinion that allows electing non-Muslim leaders is a solution and an alternative. This will affect the budgeting allocated to Muslims. For example, the budget for places of worship has been allocated from the regional budget. When leaders from the provinces and districts think that Muslims have been reluctant so far to vote for them, they will not prioritize the budget for

\footnotetext{
${ }^{47}$ For example, the case of Ja'far Umar Talib who attacked a mosque in the neighborhood who turned on the speaker loudly. There were indeed no casualties, but persecution which resulted in riots which led to tension and riots in Jayapura City.
} 
Muslims. However, when Muslims participate in the voting, the results will be different. Thus, one of the products of fiqh of minorities is electing non-Muslim leaders. This will lead to the benefit of the budget, which in this case is safeguarding assets and is part of hifz al mal which is included in the category of maslahat daruriyyah.

The maslahat hajjiyyat is to avoid difficulties. For example, it can be seen in Christmas greetings. In multi-religious countries, such as Europe and Indonesia, one family often consists of children, parents, uncles and aunts, and nieces. At the time of the holy day celebration, they wish them a happy holy day. In Arabic, it is called tahniah. The relationship between families will be difficult if they do not wish them a happy holy day. Likewise, it can also happen among classmates, or good relations between doctors and patients, teachers and students, students or lecturers. This has been stated by Yusuf Qardawi that these phenomena and events occur in society. He can conclude the issue because he has received many questions from Muslims living in Europe. $^{48}$

Based on the explanation that has been elaborated, it can be concluded that the concept of fiqh of minorities finds its basis with the concept of maqasid al-sharia. The grand concept of fiqh of minorities is based on and relies on the concept of maqasid alsharia.

\section{CONCLUSIONS}

Based on the explanation above, it can be concluded that the position of maqasid al-sharia is the basis and foundation for the concept of fiqh of minorities. The format of the maqasid al-shari'a rules in fiqh of minorities included: First, al-taysir waraf 'al-haraj (easing and taking up difficulties). Second, tagayyur al-fatwa, that is changes in the fatwa. Third, tanzil al-hajah manzilah al-darurat (needs to occupy an emergency). Fourth, 'Urf or customs in society. Fifth, Annazru ila al-Ma'alat (seeing the legal consequences). Sixth, the jamaah as the judge.

\section{REFERENCE}

'Asyur, Muhammad al-Tahir Ibn, Maqasid al-Syari'ah al-Islamiyyah, Edition II; Qahirah: Dar Al-Nafais, 2001.

Alwani, Taha Jabir, al-Maqasid al-syariah, Edition I; Washington: IIIT,1996.

Amidi, Ali Ibnu Muhammad al-, al-Ihkam fi Usul al-Ahkam, Qahirah, Dar al-Sami'i, no date.

Audah, Jaser, Fiqh Maqashid, Edition I; al-Qahirah: Dar al-Syuruq, 2007.

Ibn Manzur, Lisan al- 'Arab Edition I; Qahirah : Dar al-Ma'arif, no date.

Ibrahim, Muhammad Yusri, Fiqh al-Nawazil li al-Aqalliyyat al-Muslimah, ta'shilan wa tatbiiqan.

\footnotetext{
${ }^{48}$ Yusuf al-Qaradawi, Fi Fiqh al-Aqalliyyat al-Muslimah. pp. 124.
} 
Isma'il, Sya'ban Muhammad, al-Tasyri' al-Islami; Masadiruhu wa Atwaruh, Edition II; Mesir: Maktabah al-Nahdah al-Misriyyah, 1985.

Kettani, M. Ali, Minoritas Muslim di Dunia Dewasa Ini, penerj. Zarkowi Soejoeti, Edition I; Jakarta: PT Raja Grafindo Persada, 2005.

Mawardi, Imam, Fikih minoritas, fiqh al-aqalliyyat dan evolusi maqasid al-syariah dari konsep ke pendekatan.

Najjar, Abdul-Majid al-, Nahwa ta'shilin fiqhiy li al-Aqalliyyat al-Muslimah fi-algarb, Edition I; Al-Qahirah, Dar al-Syuruq,2006.

Qahtaini, Musfir, al-Wa'yu al-Maqashidi, Edition I; Beirut: Al-Syabakah AlArabiyyah, 2008

Qaradawi, Yusuf, Kaifa Nata'amalu Ma'a al-Qur'an, Edition I; Al-Qahirah, Maktabah Wahbah, 1999. , Fiqh al-Aqalliyyat, Maktabah Wahbah Qahirah, 2012. Dirasah fi Fiqh Maqasid al-Syari'ah; baina al-Maqasid al-Kulliyah wa al-Nusus al-Juziyyah, Kairo: Dar al-Syuruq, 2006.

Raisuni, Ahmad, Muhadarat fi maqasid al-syariah, Kairo: Darul Kalimah, 2013.

Syatibi, Abu Ishaq al-, al-Muwafaqat fi Usul al-Syari'ah, juz 1 Qahirah: Dar alTaufiqiyyah, 2003

Zuhaili, Wahbah al, Usul al-Fiqh al Islamy, Edition I; Teheran: Dar Ehsan, 1997. 